\title{
11. Between Locals: Interpersonal histories and the 1970s Papunya art movement
}

\author{
Peter Thorley and Andy Greenslade
}

Acrylic paintings from Australia's Western Desert have risen to prominence internationally since their humble origins at Papunya, NT, in 1971. Papunya holds a special place in the history of contemporary Indigenous art as the first acrylic painting community. For roughly a decade, however, from the time paintings were first produced, Papunya remained little known and the paintings went largely unrecognised both within Australia and overseas. The first decade of the movement has attracted much recent interest from scholars and observers of the art movement (for example, Benjamin and Wieslogel 2009; Berrell 2009). In its initial phase of development, the market was far smaller and more geographically restricted than today. There was no real secondary market as there is now with a multitude of dealers, auction houses and internet suppliers. Buyers were not investors and the paintings could be bought for prices very much below what they bring in the present market. During this period, there were relatively few players, which allows the early history of Papunya panting to be viewed from the perspective of key individuals and their shared experiences. These experiences are tied up in the buying and selling of the paintings and the behind-the-scenes negotiations that take place around each painting's production and acquisition.

Western Desert paintings today are generally bought by an anonymous buyer who has never met the artist. The paintings are understood and marketed in different ways - as souvenirs, primitive art or as contemporary fine artworksbut when they are bought through a commercial vendor there is little if any direct engagement between artists and buyers. Buyers are sometimes provided with documentation that identifies the artist, the title and a synopsis of the painting's content. As a result, people who otherwise have no relationship with the painter are able to gain an insight into the artist's connection to country, even though the deeper ritual significance of the painting might not have been revealed in the information given. While the sale of artworks can help to raise cultural awareness of the painting community, the way paintings are distributed through an elaborate network of intermediaries and marketed to the fine-art world as an act of individual creation tends to distance buyers from the role of the market and the collaborative process by which the paintings came into being. This, it can be argued, actively disengages those who purchase Indigenous art from the everyday experience of the artists. 
Market dynamics are critical to a broader understanding of the history of Papunya painting. From the outset, the types of paintings produced, the choice of palette and the size of the artworks have been tailored to market tastes. The provisioning of materials with which to paint, the documentation of the artist's story and the negotiation of the amount to be paid to the artist are all events in the life of a painting before it reaches the market. The market depends on these collaborations between individuals. There is both intimacy and agency between the players involved. There are stories of power and trust and of dependent relationships and close friendships. Each painting has potential to shed light on these formative events yet the stories remain, for the most part, hidden. As a social history museum, the National Museum of Australia (NMA) seeks to collect and display objects that embody individual lives and the social processes in which they are enmeshed. From the moment they come into being, objects accumulate stories associated with their production and their participation in the everyday lives of people. There is often a genuine desire on the part of buyers of Aboriginal art to empathise with the painters and their communities but the social practices that underlie the painting's construction remain largely invisible to the intended audience.

In this chapter, we want to show the potential of what we are calling 'interpersonal histories' not only for elucidating art-market dynamics but also as a means of documenting the history of individual paintings and of the painting movement itself. Here we attempt to show how, particularly in the early years, artists were active in establishing and maintaining valued relationships through which they were able to exchange paintings for cash and other desirable items. The sale of paintings cemented relationships with whitefellas, who became, in a sense, owned. The relationships were investments and were quarantined from others, as we later illustrate.

Our emphasis on inter-subjectivity sits well with the National Museum of Australia's approach to history through personal stories and life experiences that run throughout the museum's galleries. The act of acquisition is a key moment in the history of an object and the National Museum recognises this in how it defines its collections by treating each acquisition as a separate collection even if they have a similar provenance. As objects pass through long and increasingly complex chains, we often lose sight of these formative moments. Indigenous collections represent a special kind of challenge. The National Museum of Australia has inherited a large collection of Aboriginal objects, many of which are products of a nineteenth-century view of material culture that emphasises classification and description of types. Objects were collected and displayed to illustrate discrete cultural types rather than as products of intercultural contact and exchange. Artefacts were often collected without accompanying information about the artist or the circumstances behind their acquisition. Even 
so, colonial relationships are very much embedded in the objects themselves. Before the development of outlets for the sale of Aboriginal arts and crafts, all artefacts were the products of direct exchanges between producers and consumers. The acknowledgment of the inter-relatedness of object history has seen the significance of many nineteenth-century collections-once rejected as having little information of value - now re-evaluated as social history. In contrast with collectors of the past, however, buyers of Indigenous art today rarely have the opportunity to meet the artist or develop any sort of relationship, and in this way the purchase of objects becomes a mediated contact or substitute for an actual experience. In a similar way, people who come to the museum are able to have an encounter with Indigenous culture through its collections. Museum displays bring audiences face to face with real objects in a physical and embodied space - an experience that can be contrasted with a digital encounter. Yet both experiences have the potential to be intensely depersonalising. Consequently, one of the challenges for museums - in a world where communication is increasingly mediated - is incorporating a sense of the personal and interpersonal into their collections and exhibitions. In developing collections of early Papunya painting material, the NMA has been actively seeking works that illustrate these kinds of stories.

\section{Artefact Exchanges in Central Australia}

A market for Aboriginal products in Central Australia developed after the completion of the railway from Oodnadatta to Alice Springs in 1929. The trade was built initially around wood-carvings, with the watercolour painting movement emerging at Hermannsburg in the late 1930s, both of which had an influence on the 1970s Papunya painting movement.

Papunya was established as a welfare settlement in the late 1950s. When Geoff Bardon arrived there in 1971, there already were established artists and carvers who were familiar with the market and the sale of artefacts to local nonIndigenous residents of the settlements and towns and also to passers-by. As a result of Bardon's collaboration though, a new product emerged.

By the 1980s, acrylic paintings had replaced wooden artefacts as the primary source of income for Aboriginal artists in Papunya. In 1986 when one of us (PT) came to work in Kintore, a Pintupi settlement that was set up as an outstation from Papunya, Papunya Tula kept a tight rein on the production and sale of canvases, and discouraged local non-Indigenous residents from buying directly from artists. Paintings were outside the price range of most local buyers and in four years in the community PT bought only a single painting. This was bought through the company and was a painting PT had seen on a trip to Kiwirrkura 
and liked, rather than a work by a close personal friend. On the other hand, a number of close friends from Kintore were often keen to sell wooden artefacts, and PT ended up with a collection of these that he did not particularly set out to acquire; in a way, Pintupi made him a collector. This local economy based on wooden artefacts was also a significant income spinner for women artists, who at that time were not represented by Papunya Tula.

During the 1970s, before Kintore existed as a community, the art market was still finding its feet. Papunya Tula operated within the Papunya community but there was a higher turnover of staff within the company. Paintings were sold for slightly higher prices than wooden artefacts. Artists in Papunya were producing large quantities of paintings that were difficult to sell in the Aboriginal Arts Board shop in Alice Springs and many were stockpiled by the Arts Board and offered for donation to museums and art galleries, who at that time were unconvinced of their value (Bob Edwards, Personal communication, November 2009). While Papunya Tula and the Aboriginal Arts Board bought and commissioned canvases, another economy operated at Papunya, between locals, where artists sold to non-Indigenous residents with whom they worked and interacted on a daily basis. This was in addition to the tourist market, when people brought works into town to sell, or painted while they were there and sold them to whoever would buy. Sales of this type would generate direct encounters, though generally these were brief. Although not wanting to dismiss the significance of tourist sales or the Aboriginal Art Board purchases, we want to focus on exchanges 'between locals', as we have put it. In this chapter, we illustrate an example of local exchange between Kaapa Tjampitjinpa, an important artist in the early history of the painting movement, and a nonIndigenous buyer, Gwen Daniels, who worked in Papunya from 1976 to 1977.

\section{Kaapa Tjampitjinpa and the Papunya Art Movement}

Kaapa Tjamptijinpa's role as an artist and innovator was central to the birth and early development of the painting movement that started at Papunya in 1971. Geoffrey Bardon says of Kaapa Tjampitjinpa that 'the Papunya [art] movement was built around his classic artistry and his compulsive will to paint' (Bardon 1991). In some ways, the history or progression of Kaapa's work can also be seen to mirror the development of the movement itself. Kaapa was a woodcarver and watercolour artist before the painting movement began and was one of the first to transfer ritual designs onto boards with paint after Bardon's arrival at Papunya in 1971. The NMA's collection includes Goanna Dreaming at Mirkantji - one of the first works to be exhibited publicly. A carving of a 
goanna and a watercolour painting are among the works held by the museum that illustrate his early participation in the market. The NMA also holds a selection of paintings by Kaapa from the 'Big Canvas' period when the acrylic movement relied heavily on Commonwealth support through the Aboriginal Arts Board. This makes the NMA's collection of 14 works by Kaapa from various periods in a range of media especially important and interesting. Of the 14 works in the collection, however, only one painting, Kalipimpa Rain, produced by Kaapa in 1976-77, has a clearly documented interpersonal history attached (Figure 11.1). This chapter now describes the circumstances around the creation of this painting and its place in the local economy of Papunya in the 1970s. The painting was bought by Gwen Daniels, and the following account is based on a 2009 interview with Gwen and her husband, Owen, who were both in their eighties.

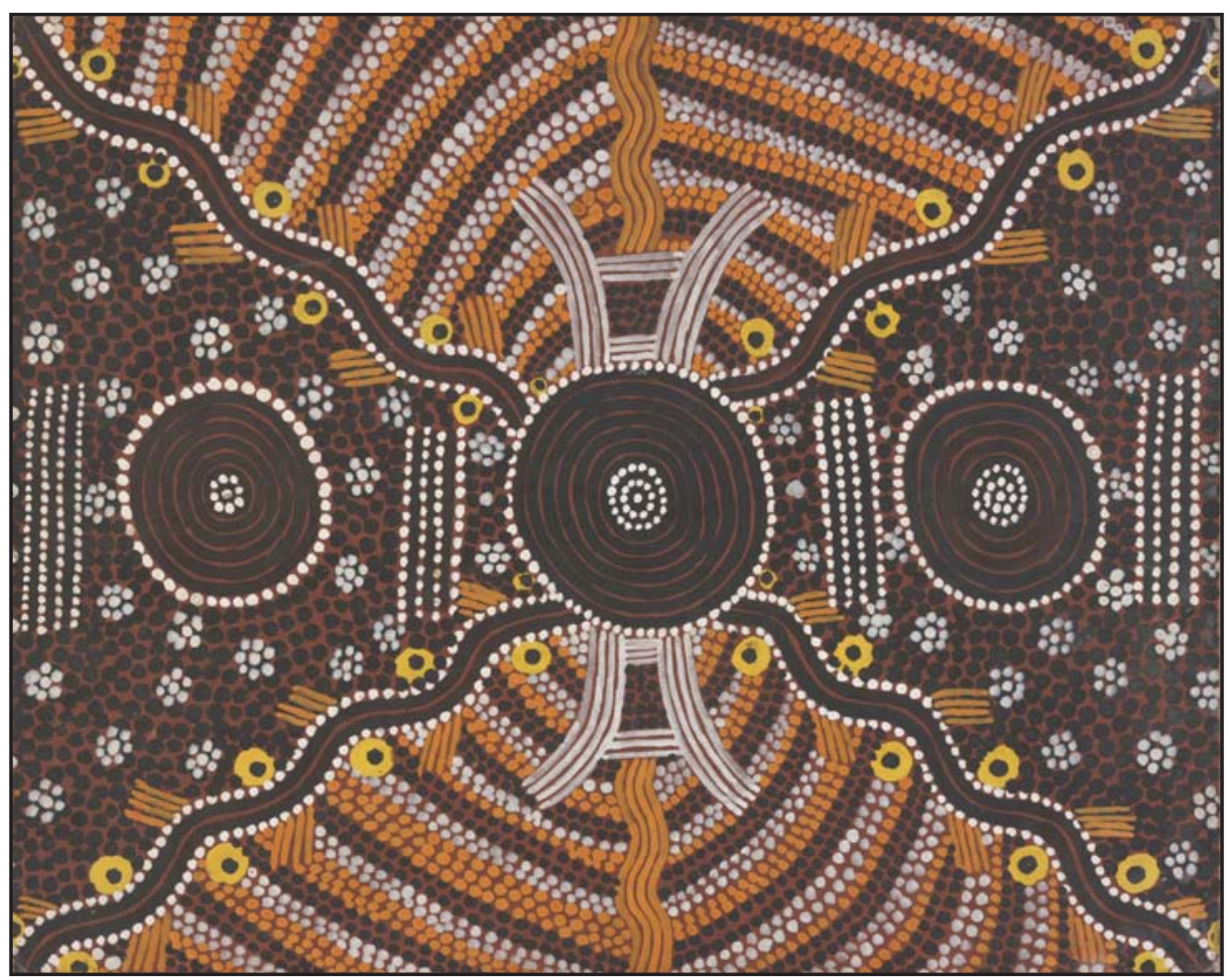

Figure 11.1 Kalipimpa Rain (more commonly known as Kalipinypa) by Kaapa Mbitjana Tjampitjinpa, painted in 1976-77

Photo: Jason McCarthy, NMA. 


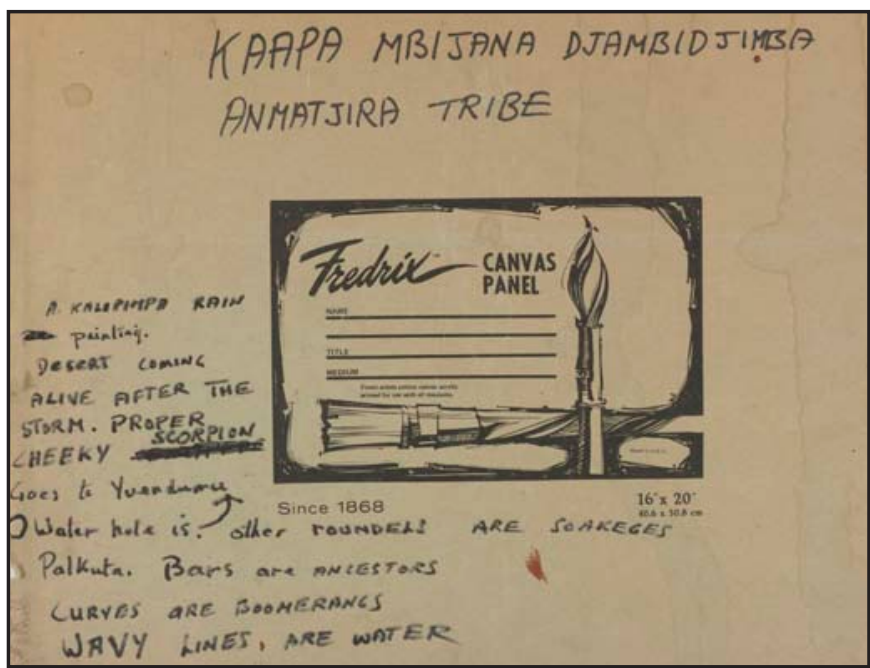

Figure 11.2 Reverse of Kalipimpa Rain by Kaapa Mbitjana Tjampitjinpa

Photo: Jason McCarthy, NMA.

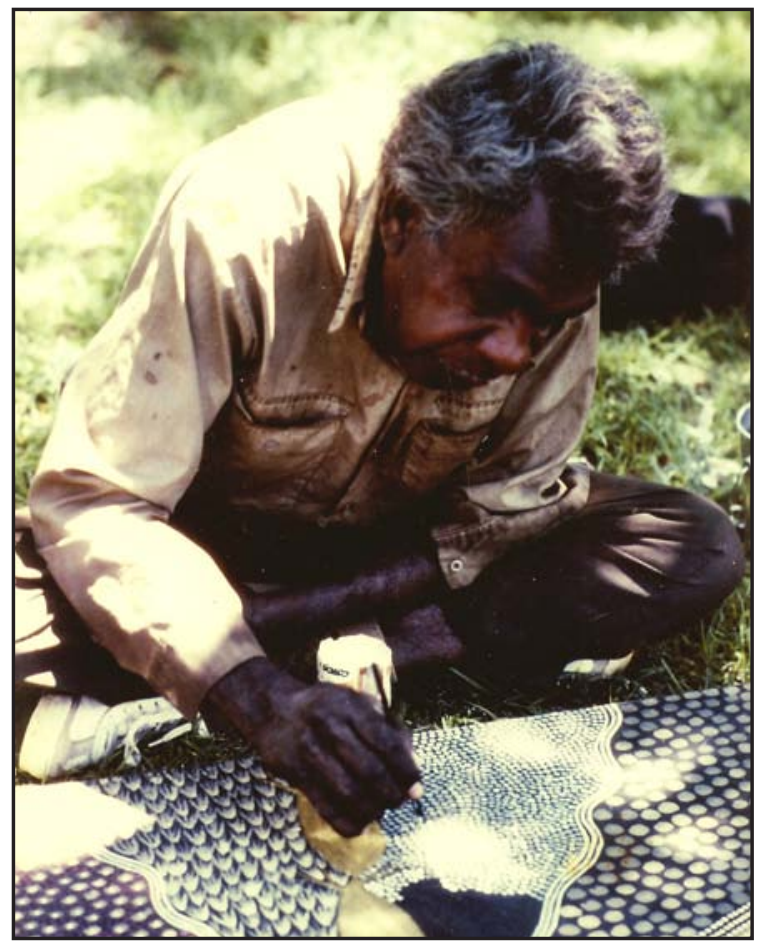

Figure 11.3 Kaapa painting in the backyard of Gwen and Owen Daniels at Papunya, 1976-77

Photo: courtesy Gwen Daniels. 


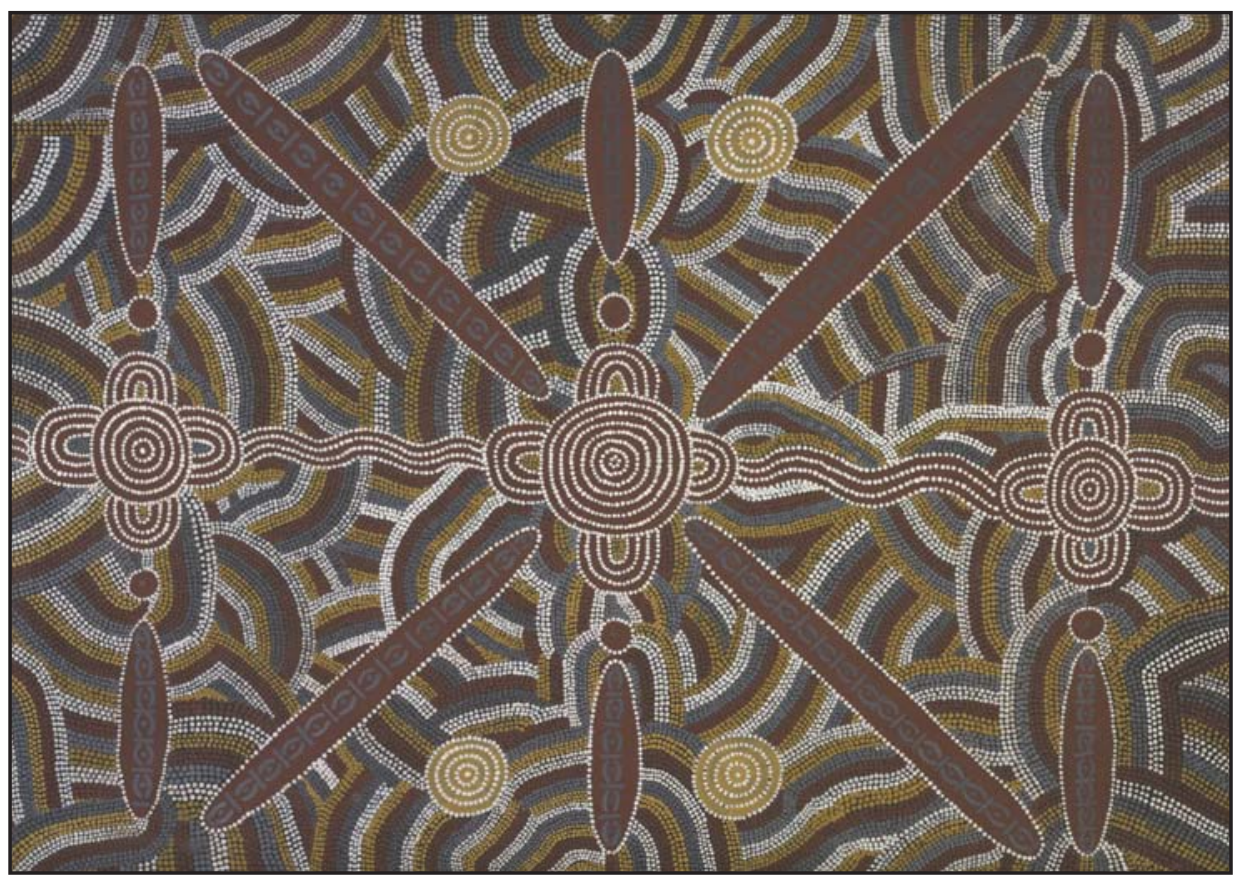

Figure 11.4 Untitled painting by Kaapa Mbitjana Tjampitjinpa, 1984. The purchase of this work, by Director, Don McMichael, was the first time a Papunya painting was acquired by the National Museum of Australia

Photo: Jason McCarthy, NMA.

Gwen and Owen Daniels went to Papunya in one of those serendipitous combinations of events that some take as meaning they were 'meant' to get there. Owen had suffered a number of heart attacks and expected that he had very little time left. They decided to use what time they did have travelling around the country, visiting outback communities, especially Aboriginal communities. During their travels, Owen's health returned to such a degree that they decided they would re-enter the workforce. Having spent a year travelling, Owen thought a job offered by the YMCA (the Y) looked appealing and he applied. He was accepted for the position of Recreation Officer for one of the Tiwi Island settlements. Owen's role was to provide options and activities for the youth of the community that could be an alternative to the growing use of alcohol.

Shortly before their departure north, they were contacted by the ' $\mathrm{Y}$ ' to tell them that, although employed for the Tiwi Islands, they were in fact to ready themselves for a term at Papunya, where someone else had decided at short notice not to take up a position. 
They arrived at Papunya to find no facilities for them, other than a house in less than perfect condition. Owen and Gwen, ever resourceful, fixed the house, then set about finding and repairing a building in which to base the recreational activities.

Gwen was given some part-time work at the women's centre, presumably for no other reason than because she was a woman. She had no training or expertise in production of fibre or the fabric work in which the women were working. Nor was her speciality in aesthetics.

At the women's centre, however, she met Kaapa. He often tried to gain entry to the centre, perhaps to access the resources for craft of one sort or another. Gwen found that if she spent time chatting with him outside on the steps, Kaapa would be satisfied and stop trying to get inside. The women inside found this rather amusing and instantly teased Kaapa as Gwen's 'boyfriend'-perhaps due to Kaapa's well-recognised succession of wives.

Gwen's lack of expertise in the art and craft arenas had implications in the transactions that would take place between herself and Kaapa. She would become a collector of his work and a supporter of the wider Papunya movement, though her intention had not been to gather so many examples of his paintings. What she did have that was of value, however, was faith in him and in their growing relationship. She found, as many before had also found, that Kaapa had a magnetic personality. When I was trying to explore this with her, Gwen could tell me only that he charmed her and everyone who came into contact with him. His nature shone out beyond all the other men at Papunya at the time. She also recognised that he could be a bit of a rogue, but that his character had a redeeming quality that kept Gwen and Owen true to him.

Gwen had time on her hands and she and Kaapa gradually developed a relationship of mutual advantage. Gwen recounts the moment she began to understand part of the nature of that relationship - though not as obviously as another colleague of ours who overheard her 'mother' angrily telling an interloper to 'clear off, this is MY whitefella'. She understood that an unspoken, formal relationship with him now existed that fitted both of their needs.

Johnny Warangkula (another of the original group of Papunya artists) had come to Gwen asking if she would buy some of his paintings only to end up in a fight with Kaapa, who was asserting his own right to have Gwen exclusively as 'his'. She became aware that part of her role with Kaapa was as his 'broker', his ready source of purchasing power and his sponsor. He was able to use her to shield himself against other white residents of the community, who from time to time would want him to paint for them but also wanted to bargain about the fee to be paid for his work. This effectively placed him at a remove from his patrons and placed him in a mastercraftsman role, with his interests mediated by a third party. 
In return, Gwen was afforded a place in the community: she was accepted in some more formal role within the structure of Papunya and she was also expected to fulfil the duties of that role. She gained some understanding of his work and some insight into 'why' and 'what' he painted. And she faithfully recorded the things that Kaapa spoke of in relation to specific paintings. She also received his friendship, which she valued highly.

This period coincided with a low-level presence of Papunya Tula at Papunya. In Gwen's understanding, to all intents and purposes, Papunya Tula did not seem to be operating. There was no-one representing the white organisational arm of the company; she saw no-one coming in to buy work apart from the occasional traveller; and no materials were being provided for the men to paint. Apart from Gwen helping Kaapa fill in his forms to keep him in government money, there was little that Kaapa could do to raise additional income in the community. And so Gwen would buy from the store in Alice Springs whatever materials she could that matched Kaapa's requirements. Often they would have fallen short of later Papunya fine-art standards, but at this period, she bought what she could - and this included the Frederix board on which Kalipimpa Rain has been made.

Gwen and Owen loved Kaapa and they were happy to give Kaapa the \$30-50 he asked for his paintings, without questioning the figure. They trusted the value that Kaapa said he placed on them. From AG's conversations with the couple, they did not seem to relish the paintings aesthetically as much as the experience that underpinned the painting and the transaction between themselves and Kaapa. They also seemed to value the opportunity to give him assistance. As confirmation of this, many of the paintings Gwen acquired are still owned by her family, despite the need to put a few pieces to auction to supply an income for family necessities.

Kaapa, in return, sold to them what he called 'proper good one story'. When supplying paintings through his 'broker', however, for other people whom he held in lesser regard or with whom he did not have an ongoing relationship, he might be very happy to sell them the other sort of painting - the ones that he termed 'proper shit one'. Those might be produced for a more general, tourist market.

Gwen and Owen gave him physical care, too. They were happy to keep their freezer well stocked from the local abattoir for Kaapa and were ready to provide him with a variety of clothes, which Kaapa was well known to enjoy.

There was, however, clearly a line that Kaapa once crossed and which still gave Gwen enormous cause for laughter as she recounted the act that counted as 'a bridge too far' in Owen's mind. Kaapa was going to town, so they had found amongst some clothing a friend had sent them a black suit, white shirt and tie for Kaapa. They had bought him a new black hat from the store and Owen 
had donated a pair of Italian-made shoes. They also loaned the use of their bathroom for Kaapa to clean himself up and get dressed in his new outfit. What Owen had not intended to share with Kaapa was his last sharp razor blade, but when Kaapa emerged resplendent from the bathroom, sporting a pencil-thin moustache, Owen knew that the blade was no more.

Kaapa showed consummate knowledge and use of economic controls and mechanisms that ensured he was involved in sophisticated commerce. The arrangement he made with Gwen, and to a lesser degree with Owen, supplied him with a ready supplementary income and all the material benefits and controls offered by a contemporary art centre.

Kaapa took up residence in their backyard for use as his painting studio. It afforded him space and comfort in which to concentrate on his art production. There was grass to sit on; there was shade; there was a ready source of food; there were no children or dogs to provide those additional accretions that many paintings bear; and there was a supply of materials and a specific, reliable customer. And fortunately for the NMA, there was someone at hand to hear the story of the painting and to record it, to appreciate it and to care for it until its place in this collection was assured.

That the relationship was more than mere economics was proved some 12 or 13 years following Gwen and Owen's eventual move to the Tiwi Islands. In 1989, when Kaapa died, his family requested that the news of his death was sent to them. And the joy with which Gwen and Owen recall the man also indicates a lasting regard for him and an emotional connection between them all.

\section{Conclusions}

The Daniels' time at Papunya coincided with a time when Papunya was little known and art connoisseurs overlooked most of the paintings produced there. The painters, Papunya Tula and the Aboriginal Arts Board were all actively promoting their product in different ways but the market continued to languish throughout the 1970s. Small-scale transactions between artists and non-Indigenous employees living in communities helped to sustain the artists through the difficult times. With its elevation to fine art and its commercial success in the international arena, Papunya painting came to take on new meanings and paintings came to be displayed and reproduced in a wide range of contexts, in which their meanings shifted in subtle and often telling ways. The further removed from their original contexts the paintings were, both in time and in distance, the greater the potential for paintings to be inscribed with other meanings and values. One of the ways we can begin to redress this shift is to focus on works that show something of the local context in which 
they originated and acknowledge the act of acquisition as a key moment in an object's history. The relationships that grew around the painting movement were all important to its long-term survival. The Western Desert artists invested in social capital to achieve their own ends and to maintain a range of channels through which they were able to access the wider economy. The success of the Indigenous arts industry is testimony to the artists' ability to deliver desired outcomes for their communities. The artists and their descendants take great pride in these achievements, which are highlighted in local accounts of the history of the painting movement.

\section{References}

Bardon, G. 1991. Papunya Tula: Art of the Western Desert. Australia: Penguin.

Bardon, G. 2004. Papunya: A place made after a story. Melbourne: Miegunyah Press.

Benjamin, R. and Wieslogel, A. (eds) 2009. Icons of the Desert: Early Aboriginal paintings from Papunya. New York: Cornell University Press.

Berrell, N. 2009. Inroads offshore: the international exhibition program of the Aboriginal Arts Board, 1973-1980. Recollections 4 (1). 